\title{
REVIEW
}

\section{On Music and Soul: Coltrane's My Favorite Things, LeRoi Jones' Black Music and Adorno's papers on Jazz}

\author{
Wilfried Allaerts \\ Biological Publishing A\&O, Erasmus MC, Rotterdam, The Netherlands
}

\section{Check for updates}

Correspondence to: Wilfried Allaerts, Biological Publishing $\mathrm{A} \& \mathrm{O}$ and Immunology Department, Erasmus MC, Rotterdam, The Netherlands: E-mail: allae002@planet.nl

Received: January 1, 2022;

Accepted: January 17, 2022;

Published: January 18, 2022

Citation: Allaerts, W. (2022). On Music and Soul: Coltrane's My Favorite Things, LeRoi Jones' Black Music and Adorno's papers on Jazz. International Journal of Arts and Humanities, 2(1): 56-69. https://doi.org/10.25082/IJAH.2021.01.003

Copyright: () 2022 Wilfried Allaerts. This is an open access article distributed under the terms of the Creative Commons Attribution License, which permits unrestricted use, distribution, and reproduction in any medium, provided the original author and source are credited.

\section{(i) 8}

\begin{abstract}
In this review, we elaborate on the contrasts between Theodor W. Adorno's philosophy of New Music and E. LeRoi Jones' reports on the Avant-Garde of Jazz in Black Music. Whereas Adorno's papers on Jazz nowadays are considered at least inadequate to describe the post-war developments in Jazz, and, according to some, rather refer to the German salon music of the Weimar Republic, an interesting key figure of the emancipation of Jazz is found in John Coltrane's music. In Coltrane's version of My Favorite Things, an audaciously musical and conceptual link is found between the popular music of the Broadway musical, the avant-garde of jazz and a famous masterpiece of the Baroque era. Consequently, building upon a statement by Blaise Pascal, the notion of passion in music, in contrast with the notion of boredom, is analyzed in relation to the personality structure of gifted individuals, as described by Kazimierz Dabrowski and followers.
\end{abstract}

Keywords: new music, Jazz, avant-garde, dialectical philosophy, passion in science and music

\section{Introduction: on popular music and boredom}

Why is it so remarkable that philosophers of recent and distant past had such an outspoken interest in the music of the masses and in opera in particular? Popular arias derived from famous operas, like these of W.A. Mozart (1756-1791), G. Rossini (1792-1868), G. Verdi (1813-1901) and others, allegedly were as 'popular' as the pop songs of the sixties and seventies of last century. Radio hit lists of course didn't exist, but the popularity of the operas could become estimated by the number of performances in opera houses since their release, the number of their visitors, or the number of records sold by record companies and the covers of these arias in popular tunes.

However, it was not because of the popularity of arias from these operas and the covers they generated, that opera became a fertile soil for philosophical analysis of popular music. Particularly famous are the discussion of W.A. Mozart's opera Don Juan/Don Giovanni (1787) by Søren A. Kierkegaard (1813-1855) [1], or the often polemic discourses about R. Wagner's (1813-1883) operas, in particular Tristan und Isolde (1865) and Parsifal (1882) by both Friedrich Nietzsche (1844-1900) [2] and Slavoj Žižek ( ${ }^{\circ} 1949$, Ljubljana, Slovenia) [3], and Theodor Adorno's (1903-1969) discussion of many modern composers, including Alban Berg's (18851935) opera Wozzeck (1925) [4]. At least popularity was not the main theme in Kierkegaard's trend-setting work [1], but another aspect of modern mass culture appears herein: the problem of boredom! Kierkegaard calls Mozart's Don Juan his most sublime, timeless work, an exalted form of sensual genius, an art form of immediate eroticism. The Danish title of the chapter in Kierkegaard's work is Vexeldrift, translated as 'crop rotation', but this isn't the only possible interpretation, if one allows for the situational digressions in the following paragraphs, related to the art of seduction, the esthetic validity of marriage and the balancing of esthetical and ethical choices in becoming a genuine personality [1]. However, the esthetical and ethical values of these examples could easily become misjudged.

Exactly in the same work, Kierkegaard opens a villainous, most ironic tirade on boredom, in response to G.W.F. Hegel's (1770-1831) adagio of dialecticism, described by Kierkegaard as the propulsion of 'thesis' by its 'anti-thesis' and 'synthesis'. Boredom is not the privilege of the masses, but the culture of the masses (proletarians) and high culture (elite) will receive a different social 'status' since the writings - in the line of Hegel's dialecticism - of Karl Marx (1818-1883) and Walter Benjamin (1892-1940). A sharp demarcation in culture between Unterbau and Überbau is born [5]. In the terminology of Benjamin [5], the traditional concepts of esthetics, like creativity, genius and eternal value are designated as negative hallmarks 
that "easily degenerate and lead into abuse in a fascist way" [5], a direct antagonism with Kierkegaard's approach of estheticism.

In the oeuvre of Adorno, on the other hand, the musical aspect of boredom obviously has a characteristic face: it is the face of Gebrauchsmusik, the music of the mass culture, the dance music, the product of commercialization and mass production [6]. Unfortunately, at least for the legacy of one of the so-called greatest philosophers of the previous century, according to Jürgen Habermas, a 'genius' that was "painfully denied (the characteristic of) triviality" [7], it is also a black-colored face. On multiple occasions, this Gebrauchsmusik, or Leichte Musik (Pop music), is associated with 'jazz music'. For Adorno, considered as belonging to the same school as Benjamin, this 'jazz music' has connotations of elite dance salons, of commerce and, hence, of 'fascist' [sic] degeneration [8]. "What hallowed jazz out is its own stupidity", he declares [8]. However, Adorno mitigates: "What is stamped out, along with it, is not the musical influence of the Negro [sic] race on the northern one; nor is it cultural Bolshevism. It is a piece of bad arts and crafts" (p. 497) [8]. Adorno was prompted to write these bitter, sarcastic lines in 1933 , shortly after the newly installed Nazi broadcasting directors had put a radio ban on 'Niggerjazz' [sic] (October 1933). The article opens with the famous blunder "that jazz had already lived out its life span and succumbed to other forms of commercial pressure, therefore, the radio ban accomplished nothing that had not already occurred from natural causes" [9].

Despite this obvious, hilariously failed prognostication, and the many occasions in his later writings, where the earlier misconceptions could have been corrected [10], Adorno in principal remains attached to his earlier ideas on jazz of the 1920s [9]. This conceptual, or even 'ideological' rigidity, almost resembling a child-like stubbornness noted elsewhere, has prompted a number of important questions. We think that these questions need an answer (see Par. 2. Adorno on Jazz), before to proceed with any serious analysis of so-called 'legitimate' jazz music [9] and the heritage of the Afro-American cultural roots in the development of twenty century jazz music, as for instance documented by the famous 'black' music critic, writer and poet, Everett LeRoi Jones (alias Amiri Baraka) (1934-2014) (Par. 3. LeRoi Jones: Black Music, the White critic and Free Jazz) [11].

First, how could Adorno, as an outstanding philosopher, not be aware of the own identity of Afro-American, so-called 'black music' and black music criticism? This is especially poignant after his return from the United States in 1953 [9], and also later, toward the end of his life (e.g. when writing the Einleitung in die Musiksoziologie, 1962) [12]. Adorno repeatedly denounces the so-called myth of an own 'black' identity, especially in relation to jazz music. Was it true (as suggested by some) that he was completely blindfolded concerning any contesting views on the cultural roots related to Afro-American music?

Second, why did so many authors took a mitigating attitude toward Adorno's misconceived identity claim between jazz music and the popular dance music, as known from the Weimar Republic (see e.g. J.B. Robinson, 1994)? Furthering this question, we wonder how Adorno's defamation of improvisation and his sarcastic viewpoint on 'amateur jazz musicians' (as being an ultimately lower grade of jazz performers, because they might have cost even less for their commercial entrepreneurs), could become an integrated reality within the recent master piece of integrationist, amateur jazz musician and mathematician, Guerino Mazzola [13, 14]? Although several authors have elaborated on the charge of racism in Adorno's comments on blacks and jazz, as well as on the refutation of this charge $[15,16]$, we will not insist on this matter. Not only, because mitigating remarks (as used by some authors) like the one that ironic imitations of racist and anti-Semitic discourses in British pre-war magazines were to be unmistakably understood (as sarcasm) by his contemporary readers, or, the argument that Adorno's anti-racist reputation would be sufficiently known for his audience, are both idle and useless in a contemporary debate.

What does merit our attention, however, is the question why Adorno found it necessary to construct an antagonizing antithetical polarization between the cultural 'insignificance ' of consumer music and the primacy of composed, so-called 'classical' music and why he found it necessary to overpaint this antagonism in a stereotypical, black and white symbolization. He could have devoted his critical notes to popular Christmas tunes as well. Or, why did he choose a temporary, would-be trivial appropriation and alienation of an Afro-American cultural heritage, namely the jazz music played by German dance orchestras in the Weimar Republic [9]? Was his blindfolded view on this twenty century surge of popular music an excuse for his ignorance, because a sustained denial of the Afro-American roots in this heritage would be harder to defend?

The latter question also relates to the methodology of the dialectical discourse, the disciplining function of serious music, versus 'bacchantic agitation' [17], the banal 'vulgarities' and the philosophical mechanism involved in dialectic musicology, according to Adorno (see Par. 5. Minimal Music and Adorno's Dialectical Method).

Finally, as we might wishfully long for an antidote against the philosophical boredom of 
adopting disciplining and regulatory constraints for musical expression, one of the most exalting exponents of our longing for freedom [14], there must be another way than the whip and camel hair's chastity coat [18]. In this paper, we found an interesting escape route through the notion of experiencing passion in music and the usefulness of little, 'favorite things' in realizing this passionate endeavor. Not surprisingly, this title refers to an adaptation of one of the most inspiring jazz interpreters, the saxophonist and composer, who shortly lived at the forefront of the Free Jazz movement, John Coltrane (1926-1967). The title My Favorite Things (recorded by Coltrane at Atlantic Records in 1961) refers to a song that became famous through the Broadway musical Sound of Music by Richard C. Rodgers (1902-1979) and Oscar Hammerstein II (1895-1960). Our cross-cultural comparison, between J.S. Bach's (1685-1750) Brandenburg Concerto No. V (1721) and Coltrane's improvisation on this popular theme, will reveal peculiar similarities, but not so much the banal empty, 'mechanical soullessness' [8] described in the mid-twentieth century's German critic (see Par. 4. Mind-set, My Favorite Things, passions and cultural context). Rather it may help us to philosophically explore the non-triviality of passion and soul in an ethnomusicological context as well as in the philosophical tradition of Blaise Pascal (1623-1662) and others. Moreover, Pascal's brief reference to the personality characteristics of gifted persons may form a key to understanding the puzzling nature of a genius

\section{Adorno on Jazz}

Although Adorno's papers on Jazz have been heavily contested and some jazz historians even have epitomized its embarrassment as "some of the stupidest pages ever written about jazz" [19], they surprisingly received a lot of attention. It is important to note that Adorno's defamatory analyses or scorn or criticism were distantly removed from a passing remark or a slip of the tongue. A quite complete overview of the historical time line of Adorno's various publications on jazz is given in J. Bradford Robinson's paper [9]. All Adorno's papers on jazz are written after the fall of the Weimar republic, namely in the period from 1933 to 1953 (except a few), but nevertheless they are, intimately connected with the music of the 1920s" [9]. Robinson gives two warnings to avoid possible 'misconceptions', before to proceed with his historical analysis: a) the misconception that Adorno's use of the term 'jazz' is what we regard as jazz today, and b) the misconception that it was 'American'. Rather, it should become clear from Robinson's analysis that he only referred to the music performed in German dance saloons in the Weimar republic, a view also adopted by others (see e.g. Leppert [2002] in [6,7].

Adorno's first paper is called 'Abschied vom Jazz' (Farewell to Jazz) [6]. It appears shortly after a radio ban on jazz music is promulgated by the radio directors (October 1933), in the year that the new Nazi-regime took power (January 1933). It is also the year that Adorno's pen pal, mentor and friend Paul Tillich (1886-1965) obtained a 'Berufsverbot': he had to abandon his position as a Professor of Theology at Frankfurt - because of his public lectures and speeches against the Nazis - and had to emigrate to the US of America. Moreover, in 1933 Adorno had become Professor of Philosophy at the same University of Frankfurt [20]. Another source, however, states that the university conferred on Adorno the habilitation (the so-called Venia Legendi, the privilege to teach) already in February 1931, although the habilitation thesis was published (a revision of the original manuscript of 1932) [21] only in 1933. As a bizarre twist of fate, it appeared on the very day (23 March 1933) that the Reichskanzler forced a constitutional reform to install himself as the dictator.

Adorno's habilitation study was entitled 'Kierkegaard: Construction of the Esthetic' [22], which, by the way, was accepted upon Paul Tillich's invitation (in 1929) to present an habilitation on Kierkegaard. The turn of Adorno's thinking and Adorno's influence on the popularity of Kierkegaard's philosophy in that time, however, is not the subject of this paper; we discussed it previously, including Paul Tillich's reflection [23] on Adorno's philosophical turn [24]. It can be imagined, however, that the fate of Adorno's mentor and of other critical minds that were threatened under the new regime, must have been intimidating for a newly installed professor. Soon, already in 1934, Adorno himself was forced into 15 years of exile, first to Oxford (UK) (1934-1938), then to the US of America (1938-1949). Nevertheless, during his first years of exile, Adorno occasionally could visit his parents and fiancé/wife in Germany [25].

However, Adorno's short 'Farewell to Jazz' (1933) was not a farewell to this musical subject, neither was it an easily forgotten side remark. In fact, it has been very surprising to note how, on the one hand, many papers or notes of Adorno were devoted to the 'non-subject' of jazz, - "jazz being not what it 'is'"(Adorno, 1937, p. 472) [8] - while on the other hand, he became involved in several 'serious' studies devoted to the new developments in (classical) music [26-28] and made significant contributions to composing 'classical' music himself. Among these, the 'Two pieces for String Quartet, op.2', 'The Piano Pieces in strict twelve-tone technique' are 
well-known [25]. Many of the themes relating to the 'failure' of jazz, that were touched upon in a 'highly compressed form' in 1933 [9], will re-appear in a more elaborate way in his following papers: according to Robinson [9] these are (I) the myth of black jazz; (II) jazz as a false utopia; (III) the limits of the technical features (of jazz); and (IV) the relation of jazz to the ruling class, in particular the elite of the Weimar republic.

Adorno's next study on the subject, entitled shortly as 'Über Jazz' (On Jazz), is written during his years in Oxford and published under the pseudonym Hektor Rottweiler (in 1937) [8,9]. In this work, a 'detailed' account of the technical characteristics of jazz are given, according to Adorno, namely that its rhythmic principle consist of 'syncopation': "Musically, this 'modernity' refers primarily to sound and rhythm, without fundamentally breaking the harmonic-melodic conventions of traditional dance music. Syncopation is its rhythmic principle"(Adorno, 1937, p. 470) [8]. In a footnote to the English translation of Adorno's text (by Susan Gillespie), Leppert (2002) refers to Robinson's paper (1994) [9] to explain that Adorno misinterpreted the Scheintakt notion as a kind of syncopation: "Adorno regards Scheintakt as a kind of syncopation. He chooses the word, which he uses repeatedly, as part of a larger rhetorical ploy to emphasize what he regards as the thorough 'falseness' of the German dance-band music - fundamentally what he means here by 'jazz' - that is the subject of his essay"(Leppert, 2002, p. 492). Robinson (1994) indeed pointed out that the term Scheintakt was coined by Weimar Germany's jazz theorists to account for what is now known as a secondary rag: "Scheintakte, or 'pseudo-bars', are created when crotchets or quavers are grouped in threes within a 4/4 metre and allowed to produce three-beat patterns extending over the normal bar lines." Robinson explains that Adorno misunderstood the nature of the Scheintakt "when he described it as a combination of $3+3+2$ eight-notes within a single $4 / 4$ measure (which is the Charleston rhythm); in fact, the Scheintakt must extend across a bar line, otherwise it cannot be heard as such. Robinson acknowledges Adorno's larger point, that the Scheintakt ultimately resolves into the basic 4/4 of the piece". (Leppert, 2002, p. 492)

Other so-called characteristics of jazz are even harder to understand from a contemporary comprehension of the twentieth century flourishing of jazz: the "mechanical soullessness or a licentious decadence" (Adorno, 1937, p. 470) [8] - although Adorno doesn't explain at all what is understood by (a) 'soul' nor decadence - ; Adorno compares the stereotypology of jazz with the stereotypology of the detective novel (ibidem, p. 472), as a metaphor to indicate the purposelessness of the individual in the embracing whole of the detective form (see our discussion of a similar argument used by Franz Kafka in [29]); furthermore, the erotic 'hits of contingency' are abhorred, such as being used in certain texts of popular tunes, the wellknown 'bananas' and 'tomatoes' (p. 486). For our readers in 2022, this undoubtedly recalls the remembrance of the recently hailed Josephine Baker (1906-1975), the first black woman, artiste, chanteuse and dancer - well-known for her 'Banana Dance' (1926) - and member of the French resistance against the Nazis, who recently was honored and re-buried in the Panthéon at Paris (November 30, 2021). And, regarding the use of vibrato singing and the use of the saxophone, it is not the demon of unconstrained (black) sexuality that Adorno abhors, but the 'old' instrument of "perversely subjecting the over-stimulated Western nerves to the vitality of blacks (Negervitalität)(sic).”(ibidem, p. 471)

For Adorno, however, the claim of a 'black' origin in jazz "doesn't say much about it, even if folkloric research should confirm the African origin of many of its practices"(ibidem, p. 477). Rather, the 'primal structure' of jazz (so-called Ur-Jazz), "most closely suggests the spontaneous singing of servant girls" (p. 478), who had not been given the opportunity to join their masters on an African safari, but subserviently awaited their return meanwhile keeping the chateau in good order (sarcasm); thus, jazz appealed to the 'upper class' (Adorno, ibidem, p. 474), as an "amalgam of march and salon music, (which) is a false amalgam: the amalgam of a destroyed subjectivity and of the social power which produces it (...)"(ibidem, p. 491).

Another more acceptable example of the use of Scheintakt and march music is found in the songs of Kurt Weill (1900-1950), which 'public success' has contributed to the success of jazz, according to Adorno (ibidem, p. 472), and not the other way round. These denials of the own ethno-musicological roots of jazz are difficult to comprehend, without, as criticized by some, adopting some rationale of dialectic reasoning in order to make Adorno's philosophy work. The etiology of jazz, as originating from a compilation of 'vaudeville' entertainment, march and salon music, an amalgam in which "elements of the comical, the grotesque, and the anal (sic!) which are inherent in jazz can therefore never be separated from the sentinel elements" (ibidem, p. 492), may seem preposterous for our contemporary readers. Moreover, it strengthens the thesis of Robinson (1994), Leppert (2002) and others, that Adorno's notion of 'jazz' has nothing to do with the Afro-American cultural heritage commonly known as such. But, the fact that so many interpreters have found justification of these denials in some scheme of ignorance of the true 'folkloristic' background, points to a deeper problem. 
Ignorance is bliss, it is said, but in some cases there is more to it. Robinson (1994) meticulously described how later publications of Adorno [30,31], even after his return from the USA in 1953 [12], had internalized certain aspects of American jazz, although "Adorno was not about to revise his notions of jazz upon contact with the American original" [9]. This remark seems contradictory to the statement that Adorno's writings about jazz had nothing to do with the 'American' tradition (see introduction to this paragraph). Examples are "the phenomenon of 'swing' (as opposed to syncopation), the vocalization of timbre and the superimposition of speech-melody" [9]. And Robinson deplores that these characteristics of what he calls 'legitimate jazz', are still lumped in one heap: they still fit into "his earlier categories and dismiss them as 'pseudo-vocalization', 'pseudo-improvisation' and 'pseudo-morphosis' “ [9]. Also Adorno's acquaintance with "the importance of the New Orleans tradition and the early black-American trumpet kings" (such as Louis Armstrong, 1901-1971), don't make him change his mind: "Once again, however, Adorno's interest attaches primarily to commercialized forms of jazz, and he sees his thoughts on 1920s popular music reconfirmed by his experience of the American culture industry" [9].

Already in his 1937 paper, Adorno makes reference to the music of Duke Ellington (18991974), the black pianist who in the opinion of Adorno was "a trained musician and the principal representative of today's 'classical' stabilized jazz, (who) has named Debussy and Delius as his favorite composers"(p. 483). Leppert (2002) spends a lengthy footnote (nr. 13) to reconstruct the influences of composers like Claude Debussy (1862-1918), Frederick Delius (1862-1934) [32], but also Maurice Ravel (1875-1937) and Igor Stravinsky (1882-1971), upon the work of the 'legendary' Duke Ellington. But it is all in vain for Adorno, "who associated him with what he regarded as 'warmed-over' impressionism."(Leppert, ibidem, p. 495). Adorno knows that "the influence of impressionism is most striking in the harmonies. Ninth-chords, sixte ajouté, and other mixtures, such as the stereotypical blue chord, and whatever jazz has to offer in the way of vertical stimulation has been taken from Debussy." (Adorno, 1937, p. 483-484) [8]. No matter how 'black jazz' has sought to integrate elements of 'legitimate white' classical music, it is all rendered suspicious as an attempt to water-down or commercialize the original. It is similar to the defamatory remarks that have been heard regarding the world tours and gigantic, commercial successes realized by 'Pavarotti and Friends': being an amalgam of opera and rock $\&$ roll artists, would have essentially forfeited - as a diluted form of opera - the very original music forms, the genuine operas of Donizetti, Mozart, Verdi, etcetera [33].

Even the challenge of a new German expert on jazz, Joachim-Ernst Berendt (1922-2000), who recalled the suppression of jazz under the Nazi-regime and who became a notorious defender of jazz in post-war Germany, is rebutted by Adorno [34]. Both authors approached their subject from entirely different angles, Robinson resumes: "Berendt from legitimate jazz, of which commercial music represents a dilution, and Adorno from commercial music, from which jazz is a failed attempt at individualization" [9]. Moreover, "this spirited rebuttal shows Adorno retrenching to some of the positions he had seemingly abandoned in the USA, among them his insistence that jazz is a white man's music to which blacks merely added the frisson of their skin color" [9]. Finally, the exchange of the generic term 'jazz' by the safer alternative 'leichte Musik' [12] is also a failed attempt to restore the damage, legitimate jazz being dealt with in passing together with operetta, musical and popular songwriting: "Not even legitimate jazz is allowed to partake of a claim to artistic status as it has constantly been co-opted by the entertainment industry" [9]. We will come back to the interesting cocktail that will come out of the mixture of operetta, musical and avant-garde jazz in a next paragraph (see Par. 4. Mind-set, My Favorite Things, passions and cultural context).

Robinson (1994) concludes that, "however tempered by his experiences abroad, Adorno never entirely left the Weimar Republic (in his head) and can only be understood in that context". This is a very peculiar conclusion, even if it may be truthful to assume that Adorno wasn't aware of the existence of black jazz critic and alternative black record labels, so that he could only experience this music from the angle of white, commercial radio stations, white record labels and white critics? Even though it may be regarded as an interesting subject for study, at least for historians, to return to the Weimar Republic, there is no point in sticking to that era for obtaining a better understanding of black music, rather than to reading and listening to the black critic (see below: Par. 3. LeRoi Jones: Black music, the White critic and Free Jazz).

\section{LeRoi Jones: Black music, the White critic and Free Jazz}

In 1972, the black 'queen of soul', Aretha Franklin (1942-2018) recorded a live gospel album 'Amazing Grace' at the New Temple Missionary Baptist Church in Los Angeles [35]. Although 
the album was a commercial success (with over 2 million copies sold in the USA), there was also a critical reception in the press. A documentary film made for Warner Bross Ltd. during the live concert, however could not be released, because of litigations instigated by Aretha Franklin [36]. Consequently, the footage remained in the vaults of Warner Bros for about 36 years. After Franklin's demise in 2018, the film premiered three months later. Footage showing the audience reveals a few pale faces amidst the mostly colored people, among them the Rolling Stone front man, Mick Jagger $\left({ }^{\circ} 1943\right.$, Dartford, UK). Listening to the voice of Aretha, and seeing her performance, together with reverend James Cleveland and the Southern California Community choir, may illustrate how the experience of the performance, cannot be seized by cognitively analyzing the notes, melody lines, harmonies or rhythmical structure of the music. On the contrary, the performance appears as a full-hearted, deeply emotional re-living of it, also thanks to the excellent camera work that enabled saving the footage. Deep emotions here mean without reservedness, as in 'going berserk'. In the words of rev. Cleveland, it is not about 'what do you sing?', but about 'who are you singing to?'. This viewpoint may also elucidate why the approach of certain white critics never touched upon the heart of gospel, jazz or soul. It illustrates the importance of the authenticity of the performers, that are actively living the message.

Adorno not only denied the black origins of jazz, he also refuted the myth of a false utopia (see above, Par. 2. Adorno on Jazz), and hence the righteousness of a black consciousness adhering to its own cultural heritage (like the black movements of the 1960s) or the social context of the Afro-American communities altogether. But the legal procedures following certain events, as exemplified by Franklin, also pointed to the latent issues of ownership and commercial rights directing the recording and filming of these cultural developments.

Exactly referring to the success of rock \& roll bands and pop groups (like the Rolling Stones) in the 1960s and beyond, Everett LeRoi Jones, renamed as Amiri Baraka (1934-2014), cautions: “pop music is a slick, 'citified' version of Rock \& Roll, a 'dollar-popularity', white version of the black origins" (p. 205) [11]. It is only an example of the discourse used by a renowned black critic, but also an immanent sentinel of the huge gap between two sides of a community, where racial integration issues are far from being dissolved: apparently, both sides are familiar with claims to the ownership of the original sources of their culture. According LeRoi Jones [37], there are two sources of black music: blues and jazz. Moreover, "jazz and also blues are Western musics (!); products of an Afro-American culture". But the 'definitions' of jazz and blues are black, "no matter the geography!". LeRoi Jones sharply distinguishes between the cultural development of these musics (in plural), which is found to be Western (not 'white'), and the cultural roots or origin, which reside in the heritage and subcultural context of the black people. "And in this sense European anything is irrelevant", he adds (p. 70).

LeRoi Jones' work can best be situated in the sixties in the geographical context of the American West coast. He became a notorious member of the group around the poet Lawrence Ferlinghetti (1929-2021), founder of the City Lights book sellers and publishers in San Francisco, California. The City Lights book store became famous as a gathering point for avant-garde writers and poets, that used to read their poetry in public. To this illustrious group also belonged William S. Burroughs (1914-1997), Alan Ginsberg (1926-1997), Jack Kerouac (1922-1969), Gary Snyder $\left({ }^{\circ} 1930\right.$, San Francisco) known as the early writers of the Beat Generation.

LeRoi Jones' book Black Music starts with an article on 'Jazz and the White Critic' (first publ. in 1963), framing the message with the opening line: "Most jazz critics have been white Americans, but most important jazz musicians have not been"(ibidem, p. 11). Theodor W. Adorno is not mentioned in his book! This opening line summarizes all the foregoing. What follows appears almost as a mirror image of what a certain Weimar Germany-derived white critic had written about the subject, and spread in a multiple of copies. "There were few 'jazz critics' in America at all until the 30's and then they were influenced to a large extent by what Richard Hadlock has called 'the carefully documented geewhiz attitude' of the first serious European jazz critics"(ibidem, p. 12). Contrary to this 'geewhiz' attitude of arousing excitement, black music is predominantly the "expression of an attitude, or a collection of attitudes, about the world, and only secondarily an attitude about the way music is made" (p. 13). Therefore, according to LeRoi Jones, the major flaw in the approach to black music is "that it strips the music too ingenuously of its social and cultural intent. It seeks to define jazz as an art (or a folk art) that has come out of no intelligent body of socio-cultural philosophy"(p. 14). A musicological analysis devoid of its sociological context is "also as limited as a jazz criticism as a strict sociological approach". Regarding the recording and notation of jazz music, he continues with a few examples: "A printed musical example of an Armstrong solo, or of a Thelonius Monk solo, tells us almost nothing except the futility of formal musicology when dealing with jazz. Not only are the various jazz effects almost impossible to notate, but each note means something quite in adjunct to musical notation. (...) The notes of a jazz solo, as they are coming into 
existence, exist as they do for reasons that are only concomitantly musical. Coltrane's cries are not 'musical', but they are music and quite moving music. Ornette Coleman's screams and rants are only musical once one understands the music his emotional attitude seeks to create"(ibidem, p. 14-15). How could someone ever defend the idea of a 'failed attempt at individualization'? Or, of a 'destroyed subjectivity' (destroyed by its fascist propensities)? (see above, Par. 2. Adorno on Jazz).

In another 1961 paper, titled 'The Jazz, Avant-Garde', LeRoi Jones makes clear that all the critics of the 'classical', pre-war or European-influenced forms of jazz, had been abundantly lifted up since the arrival of what he calls the Avant-Garde of Jazz [37]. The confinement into a 32 bar melodic structure, the rhythmical stereotypes and harmonious constraints have been replaced by a hitherto unknown manifestation of free rhythm and harmonic structure, or the absence of any structure at all, as many critics would oppose: the movement of 'Free Jazz', or, somewhat negatively called the 'New Thing' was born (Spellman, 1985, p. 83) [38]. Ornette Coleman (1930-2015) was one of the most important key figures in this transition, although also John Coltrane played an important role in preparing the road to it. "Where musicians like Coltrane, Rollins, Mingus and Russell, sought to find a way out of the harmonic maze of chord progressions, Ornette by-passed the problem. He based his improvisations on melodic and rhythmic planes, developing the solo along a freer-ranging logic than harmony had allowed." [39]. In the words of A.B. Spellman (1985), author of several biographies on the front men of jazz: "Strict boundaries had formed around the frontiers of jazz improvisation; and seemingly only two men, John Coltrane and Cecil Taylor, had the heart to go beyond them. Ornette Coleman would change all that" (p. 80). Not only would Coleman push jazz improvisation to its limits, he would destroy the limits. "Such modernists as John Coltrane and Jackie McLean admit that hearing Ornette has opened their own ears to new rhythmic possibilities in both group and solo playing"(p. 82). Coltrane had started his musical career in the band of Dizzy Gillespie (1917-1993) in the 1950s and had joined the 'classic' Miles Davis Quintet in 1955 [40].

The innovations set forward by the Ornette Coleman Quartet, consisting of Coleman (saxophone), Don Cherry (trumpet), Charlie Haden (double bass) and Billy Higgins (drums), were first presented in the fall of 1959 in New York. It was considered the most serious challenge of the New York jazz establishment since Charlie Parker (1920-1955), founder of the Bebop, came out of Kansas City in 1939 [39]. Ornette was the most iconic figure of the quartet, and not only because of his 'weird looks' (Spellman, ibidem, p. 109). Following a confession of Coleman at the Lenox School of Jazz (NY) that he didn't "know how it's going to sound before I play it" (p. 83), an extra-ordinary image of indefiniteness was pictured. The indefiniteness of not knowing how the music was going to sound before it was played enhanced its emotional expression. Together with the facts that Coleman was entirely self-taught and that many of his followers had a greater technical knowledge of the saxophone than he did, created a sound that was so individualistic that it was almost impossible to approximate. Nevertheless, around 1966 his 'pure' music had developed "into a virtuosity in which the climaxes are set up as carefully as in a symphony"(p. 83).

Ornette was not opposed to inviting 'white' musicians in his group, on the contrary, for some instruments they were simply 'the best'. Charlie Haden (1937-2014), a bassist from Missouri, was one of the three white musicians that ever played with Ornette Coleman for any length of time - all being bassists -, but in the words of Ornette: "Charlie Haden was probably the most natural of all three white bass players I've ever used. The only thing that got Charlie confused was that he finally became aware that he was playing with Negroes and that made him paranoid, as if the situation was reversed, you know." (Spellman, 1985, p. 140-141).

In hindsight, it could have been expected that the Ornette Coleman Quartet would raise thrills of excitement and enthusiasm as well as fierce criticism, contempt and even unfiltered racism. Despite its successes, acknowledged by influential musicians like composer-director Leonard Bernstein (1918-1990) and Cool Bop figurehead Miles Davis (1926-1991), Coleman had to fight the prejudicial and harsh financial conditions of the (New York) jazz scene and the destructive mechanisms of the underground scene too. Spellman testified that Ornette himself did not use addictive drugs, although "at times he has had to work with bands in which the majority of the musicians were addicts. (...) his sidemen sometimes appeared for work without their instruments, which were in the pawnshop; on some occasions, if their habit called, they did not show up at all. Thus Ornette, the leader and non-user, would have to dig into his pocket for loans for his sidemen (... )"(ibidem, p. 133).

In order to compare the contribution of Coleman, Taylor and Coltrane to the avant-garde of jazz, Spellman remarked that all three were working 'on entirely, though interrelated, principles': "Coleman's main contribution to jazz may be said to be rhythmic, even though there has been considerable discussion of his tonality. Coltrane's is harmonic, setting, as he does, his wildest explorations against definite chordal patterns (which Coleman always tried to avoid). Taylor is 
involved with the construction and the organization of sound" (ibidem, p. 126). Taking together, the innovations forwarded by these jazz front men ranged over rhythm, harmony and sound of modern jazz. In the following paragraph, one aspect of the work of John Coltrane is elaborated further, because it may explain some aspects of the mind-set of certain individuals and their cultural context.

\section{Mind-set, My Favorite Things, passions and cultural context}

The preceding paragraphs to my opinion illustrate the importance of the cultural environment on the discourses of the subsequent authors. Not only the languages of origin (German American English) are different, also the vocabularies and literary styles greatly differ. The question rises whether or not Adorno's mind-set, the great philosopher of the Frankfurt School, was caught in the same cultural enclave of post-war Germany as he had experienced before the war? How much the war had changed that society, in his mind certain characteristics had remained unchanged. At least, this is what the studies of Robinson (1994) and Leppert (2002) seem to suggest (see Par. 2. Adorno on Jazz). The question whether Adorno was excluded from the possibility to contact the world of black music critics, or from the black communities of the USA altogether, may seem difficult to answer at present. The fact that both subcultures spoke a different 'language', however, is obvious from the written testimonies.

On the other hand, the following case may indeed demonstrate that in the black 'subculture' serious attempts to integrate elements of 'white' music had occurred. In his 1961 record My Favorite Things [41], John Coltrane uses a theme from the popular Broadway musical Sound of Music (1959) [42], composed by Rodgers and Hammerstein II. The musical is based on a fictitious story taking place during the Anschluss of Austria in 1938 by the Germans. In the song My Favorite Things, the protagonist Maria von Trapp sings of a list of little things that she takes in mind when times are getting difficult. We here cite the text at full length, because it is our wish to pay respect to the often neglected contribution of the songwriters [42]:

"raindrops on roses and whiskers on kittens,

bright copper kettles and warm woolen mittens

brown paper packages tied up with strings

these are a few of my favorite things

cream colored ponies and crisp apple strudels

door bells and sleigh bells and schnitzel with noodles

wild geese that fly with the moon on their wings

these are a few of my favorite things

girls in white dresses with blue satin sashes

snowflakes that stay on my nose and eyelashes

silver white winters that melt into springs

these are a few of my favorite things

when the dog bites

when the bee stings

when I'm feeling sad

I simply remember my favorite things

and then I don't feel so bad" $(2 x)$

(Rodgers and Hammerstein, 1959).

The recital of apparently unimportant events - although a bit fairy-like - that may flourish our day, reflects the arbitrariness of ordinary, daily experiences. So may be our musical preferences, this musical choice suggests, as is expressed in an old Latin saying 'de gustibus et coloribus non est disputandum'. In other words: discussing matters of taste and (musical) preference is pointless. It is called small talk. But for the innovators of jazz, as LeRoi Jones [37] pointed out, it was a matter of survival, not only to become accepted by the jazz community, but also to demonstrate that jazz was capable of claiming its status of 'art' music.

In the instrumental version of My Favorite Things by Coltrane, something peculiar happens. Not only the 'lyrically lovely' sound of the (originally soprano) saxophone [40], but also the construction of the 17:31 minute piece is extra-ordinary. However, it was Coltrane's wish not to print 'liner notes' on his albums expressing the music structure being such-and-such [43], and although not much literature on this record is found, I noticed the following features. (Writing about these features, we may risk to fail to respect his wish and posthumous imperative to let his music speak for itself - or through its recording - for which we hope to apologize). After the initial exposition where the integral melody of the strophe is played, the melody line is repeated a number of times but in distinct abridged expositions, after which harmonic improvisations are 
inserted. Towards the end of the piece the abridged melodic lines return and finally the whole musical strophe is repeated. When I heard Coltrane's performance, I immediately remembered I had heard such a technique before: it is similar to the fractionated repeats of the opening exposition in J.S. Bach's Brandenburg Concerto No. V (1721). Also here, the full theme is only given twice, at the opening and at the end; fractions of the theme are alternatingly repeated with advanced improvisation-like passages of the harpsichord. Allegedly this was the first work of J.S. Bach, where the harpsichord is used as a solo instrument and for which large improvisation-like passages are noted, as if Bach would have thrown off the yoke of classical baroque form. To my opinion, Coltrane could not have chosen a better theme to demonstrate his throwing off the classical forms of jazz. Of course, there could be many more works to choose from. But, like many composer and songwriters have their quintessential piece of work, like Bob Dylan $\left({ }^{\circ} 1941\right.$, Duluth, Minnesota) wrote the Sad-Eyed Lady of the Lowlands (1966) [44], Coltrane had My Favorite Things. By the way, singer-songwriter Tom Waits ( ${ }^{\circ} 1949$, Pomona, CA, USA) referred to this Dylan song as 'a dream, a riddle and a prayer'. It is striking to read how often the musical performance of John Coltrane, the creative genius of A Love Supreme (1965) [40] and many other records, is associated with the term 'love' [43], and with its cultural mirror image: passion (see below).

Upon invitation, I happened to give an audio demonstration of the two musical expositions of Coltrane My Favorite Things and Bach's Brandenburg fifth concerto, during a lunch lecture at Twente University [45] devoted to the notion of passion in science and music. Passion in science is what makes us gossip about our favorite subject [46], or what makes us feeling bored about the passion of other passionate people [47]. For, one of the first lessons of social life is that the favorite of one is a bore to the other: there isn't a transitivity property in the mind-set that produces a passionate affection to certain things or elements of culture, except for the groupies of like-minded spirits. Although some have attempted to create a universal formalization system of for instance digitalized music [14], it is hard if not impossible to create uniform standards for comparing cultural forms that at the same time carry the heritage and expressive means for their cultural identity.

What is recognizable as a cross-cultural phenomenon, is that each culture harbors its geniuses, figureheads of their cultural tradition or that thrive on top of the cultural development of a certain period. Being passionate about the subject of their tradition or discipline is an important hallmark. This is beautifully expressed in one of the earliest authors of seventeenth century science, physicist, mathematician, and philosopher Blaise Pascal (1623-1662):

“(... ) A mesure que l'on a plus d'esprit, les passions sont plus grandes, parce que les passions n'étant que des sentiments et des pensées, qui appartiennent purement à l'esprit, quoiqu'elles soient occasionnées par le corps, il est visible qu'elles ne sont plus que l'esprit même, et qu'ainsi ells remplissent toute sa capacité. Je ne parle que des passions de feu, car pour les autres, ells se mêlent souvent ensemble, et causent une confusion très incommode; mais ce n'est jamais dans ceux qui ont de l'esprit. Dans une grande âme tout est grand. L'on demande s'il faut aimer. Cela ne se doit pas demander, on le doit sentir (...)” [48].

Although the latter source strictly describes the 'passions in love', the cited fragment shows that it applies to all thoughts and feelings of a 'gifted' person. Well-known geniuses like the cited Pascal, but also figures like Albert Einstein, W.A. Mozart and also Theodor Adorno, excelled in their passionate affections to their subject (science, music,..) as well as to the people in their social environment. This condition of the mind has been well documented since, following the study of correspondence, personal documents of a great number of famous people. Moreover, these gifted individuals appear to display a distinct number of personality characteristics, called over-excitabilities, after the work of Kazimierz Dabrowski (1902-1980) [49,50]. Dabrowski developed his so-called Theory of Positive Disintegration (TPD) [51] during his experiences in World War I (as a child) and WW II (as a Polish psychologist) evaluating the most inhuman conditions (in the camps) as well as the acts of the 'highest human character' [52]. It is not much of a speculation - although not (yet) confirmed by personal medical records - that the very gifted Theodor Adorno was a genius in (classical) music and in philosophical writing, but not so much in empathically reading his black fellow-men's culture. Like the actor dr. Sheldon Lee Cooper (alias Jim Parsons, ${ }^{\circ} 1973$, Houston, Texas) in the comedy series The Big Bang Theory [53], social empathy probably wasn't his strongest asset. One example of the many, prominent personalities that criticized Adorno's oeuvre on the philosophy of new music, was the composer Luciano Berio (1925-2003):

"It's not easy to completely refute anything that Adorno writes - he was, after all, one of the most acute, and also one of the most negative intellects to excavate the creativity of the past 150 years... He forgets that one of the most cunning and interesting aspects of consumer music, the mass media, and indeed of capitalism itself, is their fluidity, their unending capacity for adaptation and assimilation." (L. Berio, 1985) [54]. 


\section{Minimal Music and Adorno's dialectical method}

Having read the devastating criticism of someone like Luciano Berio (see above), it is difficult to adopt a neutral view on the philosophical writings of Adorno, especially when regarding the musical developments of the twentieth century. Whether or not a mitigating or reconciling attitude [9] is defendable, or whether his personality structure might explain his stubborn views on jazz, but also his negative sayings like a 'dismal Bohemian prank' [25], 'Sacre und Negerplastik' [55], aiming at the music of Igor Stravinsky, or like the 'reactionary composition tendency' of Paul Hindemith (1895-1923) [26], as well as negative remarks about George Gershwin (1898-1937) and others, remains a matter of our collective consciousness.

In an interview broadcasted on the Dutch radio, the American composer John C. Adams ( ${ }^{\circ}$ 1947, Worcester, MA, USA) remembers the negative attitude towards Minimal Music too, especially in the early days of the achievements of Steve Reich ( ${ }^{\circ} 1936$, Broadway, NY, USA) and Philip Glass ( ${ }^{\circ} 1937$, Baltimore, MD, USA) and himself [56]. His piece Naive and Sentimental Music (1999) therefore could be seen as an answer to that restrictive attitude: "music is allowed to (or should) try to connect with people, in order to give them a 'good feeling'..." [56]. Unlike in the 1970s, for instance at the premiere of Steve Reich's Music for 18 Musicians (1974-1976), the public reception of Minimal Music has reached enormous popularity, at least in some parts of the world.

The critical attitude of Adorno, however, has to be understood within his philosophical engagement, his attempts to apply the method of dialectical reasoning to music (criticism). The reproach formulated by Lorenz Jäger that Adorno's 'Achilles heel' consisted of placing "almost unlimited trust in finished teachings, in Marxism, psychoanalysis, and the teachings of the Second Viennese School" [57] summarizes a great deal of today's reservation towards Adorno's philosophy of 'New Music'. Indirectly, one could also add the heritage of G.W.F. Hegel and S.A. Kierkegaard's refuting of Hegel's Idealism - to Adorno's credentials. Kierkegaard, the adversary (Widersacher) to Hegel, in turn was strongly criticized by Adorno in the 1962 Appendix [58] to his 1933 habilitation thesis on Kierkegaard's esthetics [22, 24]. Adorno's positive ambition to break a lance for the 'New Music' (to start with the second Viennese School, i.e. the composers Arnold Schoenberg, Anton Webern and Alban Berg) but also the symphonic oeuvre of Gustav Mahler (1860-1911) [59], is clearly explained in his Kranichsteiner lecture on Schoenberg's counterpoint (1956) [60]:

"Indeed, this nonsense flourished for a time when, influenced by Kurth's slogan about linear counterpoint [61], people imagined that the liberation of music from the restriction of tonality was in fact a license to write anything at all. (...) I had already discussed this point thirty years ago with Eduard Erdmann (1896-1958), who claimed that, essentially, everything is permitted today and everything is open, and at the time I tried, no doubt in a clumsy and halting manner, to show him that precisely the opposite is the case. And that is how it is with harmony too. So you should not think that harmony is of no consequence in modern counterpoint. I once said in the Philosophy of New Music [62] that, just as the problems of harmonic connections are really problems of counterpoint - that is, the way to connect harmonies in meaningful ways is to ensure that the movement of voices makes sense - so too one can say, conversely, that the problems of counterpoint are really problems of harmony - that is, they consist in whether the composer succeeds in connecting the simultaneous voices to one another in such a way that they also make sense as simultaneities. (... )"

Given this personal testimony of Adorno [60], it appears that his attempts to construct a system of constraints for a permitted harmony or counterpoint in the 'new music', de facto is based on a post-renaissance, classic western conceptualization of polyphony as a pattern of simultaneities (in contrast to the earlier renaissance polyphonic conceptualization, see $e . g$. the Berlin musicologist Carl Dahlhaus [1928-1989] in [14]). This however doesn't mean that the Renaissance concept of polyphony was free from harmonic restrictions, well on the contrary. Following this insight, one can imagine that Adorno still had a Sisyphean task to catch up with the musical novelties that awaited him after the war and the subsequent revolutions in (westernized) music. Obviously, such an analysis would go beyond the scope of the present article.

On the other hand, the dialectical method, the disciplining function of dialectics or, the Negative Dialectics [63] as opposed to the Hegelian method, would offer interesting perspectives for musicological analysis of the twentieth century [64]. No matter how balanced such a culturally untainted analysis might look, the notion of 'soul' in music, like it is well-embraced in non-western cultures, seems incompatible with dialectic reasoning. 'Soul', as well as 'passion' and 'love' are tainted notions in neo-Marxist literature, or, as Slavoj Žižek unfolds with 'courtly love' [65], they become objectified in the most vulgar way [66]. Although the notion of the 
mind as a recipient for experiencing the soul of music does not a priori exclude a state of mental emptiness, or the so-called 'objectless interiority' (which Adorno found incommensurable in Kierkegaard's philosophy) [58], however, the intellectual adversity against emotional experience does. When a person is overwhelmed by emotions, there is no sharp distinction between one emotion and another, they coincide all in one. "Music unfolds itself through analysis", Adorno pleads [67]. Musical analysis for Adorno originates from the instruments of language and dialectic reasoning. Paying tribute to the severity of Plato's Republic, sensuality is considered 'enfeebling and incapacitating heroic behavior' and "whoever who devotes himself to (the dulled charms and furnished models of the familiar) is as malicious as the Greek thinkers once were toward oriental sensuality" [17]. Equally, the statements of "ideologies of primitivism and return to nature" being 'handed down from above', instead of "assisting the opposition of those excluded from culture to find expression" [17], make us smile, whether or not the echoing of these words in the contemporary world may be considered acceptable forms of irony. When the American composer, jazz musician and songwriter Frank Zappa (1940-1993) visited Prague on June $24^{\text {th }} 1991$ [68], as one of the first visited cities of the former East-European Warsaw Pact (1955-1991), he was treated like a hero, a harbinger of liberalism, an exponent of a culture forbidden until then. For the former political authorities, Zappa was definitely a hallmark of forbidden music, whether it was called jazz or otherwise [68].

\section{Concluding remarks: claustrophobia and boredom}

To conclude, starting with Adorno's statement of "assisting the opposition of those excluded from culture to find expression" [17], it became evident that Adorno's enormous oeuvre did not help the Afro-American, nor the black and/or colored communities to reclaiming their cultural heritage. The continued denials of at least a shared heritage in the origins of blues, jazz and soul music is bitterness at its purest essence, a missed chance forever. Also, it seems that the bridging of the gap between the powerless, devoid of production means and the elite controlling the media and entertainment industry, was not at least affected by Adorno's philosophical, sociological or political heritage. This may suggest that Adorno's oeuvre on the whole did not succeed in achieving its dialectical premises, or negatively stated, it resulted in an overall negation of its ambition. Whether to call such an achievement 'negative dialectics', or, referring to one of Adorno's sayings about jazz music as a "sadomasochistic character and 'commodity fetishism' of the mass culture" [17], conferring upon his dialecticism the character of sadomasochism, in our opinion would be inappropriate. Rather we would like to adhere to the saying of the French composer Camille Saint-Saëns (1835-1921) that "there is nothing more difficult than speaking about music" [69], and remain silent. Or, as expressed posthumously by John Coltrane's relatives that no explanation, no 'liner notes' should be given accompanying the recordings of his music [43], in which we failed as much as the author of that personal testimony, the question is returned as to "What is the point of writing about music at all?".

Although a rhetorical question, we suggest to answer that question with a return to the original theme of 'boredom' (see Par. 1. Introduction: on popular music and boredom). What Adorno experienced in his everyday encounters with music on radio, television and in public spaces, was a terrifying mood of boredom [67], almost resulting into a state of claustrophobic fear of the music of the mass culture. Apparently, this disgust of the mass culture became a driving force throughout his oeuvre. Interestingly, claustrophobia, whether elicited by a certain environment or provoked by its (local) subculture, and boredom (in an environment, with a certain subculture) are related states of the mind. Unfortunately, as Kierkegaard already pointed out [1], it is the proclamation of rigid constraints (out of a certain fear), that procured the conditions for boredom, as well as for claustrophobia, for those who were frightened by it. This happened with Hegelian philosophy and followers (according to some) [70] and in certain political regimes that, ideologically speaking, were based on these philosophies, as well as in dialectical philosophy of music. Therefore, as the passions and favorites of many gifted people revealed, there may indeed be found an antidote to boredom, resurging into human culture at times when it is least expected.

\section{References}

[1] Kierkegaard, S. A. (1843, 2000). Enten-Eller. (Dutch translation by J.M. Marquart [2000], Of/Of. Een levensfragment uitgegeven door Victor Eremita. Amsterdam: Boom).

[2] Nietzsche, F. (1888). Der Fall Wagner (Letter sent from Torino). In: P. D'Iorio (1975, Ed). Digitale Kritische Gesammtausgabe Werke und Briefe (eKGBW), digital version of German reference edition of Nietzsche's works, posthumous fragments, and correspondence edited by G. Colli and M. Montinari 
(Friedrich Nietzsche Werke, Kritische Gesamtausgabe (KGW), Berlin/New York, 1967 and Nietzsche Briefwechsel. Kritische Gesamtausgabe, Berlin/New York: de Gruyter, 1975).

[3] Žižek, S. (2006). La Seconde mort de l'opéra. (French transl. from English, by G. Brzustowski) Dijon-Quetigny: Éditions Circé.

[4] Adorno, Th. W. (1929, 2002). The Opera Wozzeck. (Engl. Transl. by S.H. Gillespie). In: Theodor W Adorno. Essays on Music, selected, with introduction, commentary and notes by R. Leppert (Ed.) (2002), pp. 619-626, Berkeley, Los Angeles, London: University of California Press (translated from 1929 original of Th. W. Adorno, Gesammelte Schrifte, Vol. 18, pp. 472-479).

[5] Benjamin, W. (1936). Das Kunstwerk im Zeitalter seiner technischen Reproduzierbarkeit. Zeitschrift für Sozialforschung (Herausgabe in Walter Benjamin [posthumously edited with co-operation of Theodor Adorno \& Gershom Scholem, re-edited by Rolf Tiedemann \& Hermann Schweppenhäuser] Gesammelte Schriften, Band I,2. Frankfurt a. Main, Suhrkamp Verlag, 1972-1989; Suhrkamp Taschenbuch Ausgabe, 2010)

[6] Adorno, T. W. (1933). Abschied vom Jazz. (Farewell to jazz, Engl. Transl. by S.H. Gillespie). In: Theodor W. Adorno. Essays on Music, selected, with introduction, commentary and notes by R. Leppert (Ed.) (2002), pp. 496-500, Berkeley, Los Angeles, London: University of California Press. (Originally publ. Abschied vom Jazz, in Europäische Revue, 9, pp. 313-316, reprinted in Gesammelte Schriften, XVIII (1984), pp. 795-799).

[7] Habermas, J. (1992). A generation apart from Adorno. Interview with J. Früchtl. Translated by James Swindal. Philosophy and Social Criticism, 18(2), 119-124. https://doi.org/10.1177/019145379201800201

[8] Adorno, T. W. (1937). Über Jazz. (On Jazz, Engl. Transl. by S.H. Gillespie). In: Theodor W. Adorno. Essays on Music, selected, with introduction, commentary and notes by R. Leppert (Ed.) (2002), pp 470-495, Berkeley, Los Angeles, London: University of California Press. (Original publ. Üeber Jazz [pseud. Hektor Rottweiler]. Zeitschrift für Sozialforschung, 5. Reprinted in Gesammelte Schriften, XVII [1982], pp. 70-100).

[9] Robinson, J. B. (1994). The jazz essays of Theodor Adorno: some thoughts on jazz reception in Weimar Germany. Popular Music (Cambridge University Press), 13(1): 1-25. https://doi.org/10.1017/S0261143000006814

[10] Adorno, T. W. (1953a). Zeitlose Mode: Zum Jazz. (Timeless fashion: on jazz). Merkur (June 1953), reprinted in Prismen and Gesammelte Schriften, X/1 (1977), pp. 123-137 (fide: J.B. Robinson, 1994, p. 24.) (not included in R. Leppert's [2002] compilation, see footnote 6).

[11] LeRoi Jones, E. (Baraka, I. A.) (1967). Black Music. New York, Madison Avenue: Quill, 222 p. (ISBN: 0-688-24344-4)

[12] Adorno, T. W. (1962). Einleitung in die Musiksoziologie (Frankfurt). (Engl. Transl. by E.B. Ashton [1988])(fide: J.B. Robinson, 1994, p. 24).

[13] Mazzola, G. (2018). Structure Theory of Performance (Part VIII), Mathematics of Gestures (Part XVI) and Gestures in Music and Performance Theory, and in Ethnomusicology (Part XIX) containing Reviewing Flow, Gesture, and Spaces in Free Jazz (Chapter 84). In: G. Mazzola, The Topos of Music. Vol II: Performance and Vol III: Gestures. Springer International Publishing AG (Part of Springer Nature). https://doi.org/10.1007/978-3-319-64481-3_29

[14] Allaerts, W. (2021). On music and computability: Contrasts between Harry Partch's Bitter Music and Guerino Mazzola's Topos of Music. International Journal of Arts and Humanities, 2(1), 44-55. https://doi.org/10.25082/IJAH.2021.01.002

[15] Nye, W. P. (1988). Theodor Adorno on Jazz: A Critique of Critical Theory. Popular Music and Society, 12(4), 69-73. https://doi.org/10.1080/03007768808591335

[16] Wilcock, E. (1996). Adorno, Jazz and Racism: ‘Über Jazz’ and the 1934-1937 British Jazz Debate. Telos, 107, 63-80. https://doi.org/10.3817/0396107063

[17] Adorno, T. W. (1938). On the Fetish-Character in Music and the Regression of Listening. In: Gesammelte Schrifte, XIV, pp. 14-50 (Frankfurt) and in: Theodor W. Adorno. Essays on Music, selected, with introduction, commentary and notes by R. Leppert (Ed.), new Engl. transl. by S.H. Gillespie (2002), pp. 288-317, Berkeley, Los Angeles, London: University of California Press.

[18] Sloterdijk, P. (2009). Du mu $\beta$ t dein Leben ändern. Frankfurt am Main: Suhrkamp.

[19] Hobsbawm, E. (1993). The Jazz Scene. New York, p. 300. (fide: J.B. Robinson, 1994, p. 1).

[20] Tillich, P. (1953). Letter to T.W. Adorno, written in Aberdeen, Scotland, 23 November 1953 (Berlin: Walter Benjamin Archiv, TWAA_Br_1548/1).

[21] Adorno, T. W. (1966). Notiz (Berlin: TWAA).

[22] Adorno, T. W. (1933). Kierkegaard: Konstruktion des Ästhetischen. (Herausgegeben Rolf Tiedemann, unter mitwerkung von Gretel Adorno, Susan Buck-Morss und Klaus Schulz, Suhrkamp Verlag 1962). Frankfurt am Main: Suhrkamp Taschenbuch Wissenschaft 1702, Erste Auflage 2003.

[23] Tillich, P. (1952). The Courage to Be. Yale University Press. Binghamton, NY: Vail-Ballou Press.

[24] Allaerts, W. (2017). When Teddy met Paulus (Tillich). Adorno on Kierkegaard again, 'das Ganze und die Innerlichkeit'. bi-logical, 6(2), 45-52.

[25] Müller-Doohm, S. (2005). Adorno: A Biography. Malden, MA: Polity Press.

[26] Adorno, T. W. (1941). Zur Philosophie der neuen Musik. (Original typescript, not publ., Berlin, TWAA_Ts_1302). Re-edited and published [1949, 1975]: Philosophie der neuen Musik). Gesammelte Schriften, XII (Hrsg. Rolf Tiedemann, 1976.), Frankfurt am Main: Suhrkamp Taschenbuch Wissenschaft 239. 
[27] Adorno, T. W. (1993). Beethoven. Philosophie der Musik. In: Nachgelassene Schriften, Abteilung I: Fragment gebliebene Schriften, Band 1 (Hrsg. Rolf Tiedemann, 1994). Frankfurt am Main: Suhrkam$\mathrm{p} /$ Insel.

[28] Adorno, T. W. (1955-1966, 2014 Ed). Kranichsteiner Vorlesungen. In: Nachgelassene Schriften, Abteiung IV, Vorlesungen, Band 17 (Hrsg. Klaus Reichert und Michael Schwarz, 2014). Berlin: Suhrkamp Verlag.

[29] Allaerts, W. (2016). Walter Benjamin: facing the Angel of Oblivion. Between the Storms of Progress and the Ruins of History. bi-logical, 6(1), 44-55.

[30] Adorno, T. W. (1941). Reviews of American Jazz Music by Wilder Hobson [1939] and Jazz: Hot and Hybrid by Winthrop Sergeant [1938] in Studies in Philosophy and Social Science, 9, pp. 167-178. German original in Gesammelte Schriften, XIX (1984), pp. 382-399. https://doi.org/10.5840/zfs19419117

[31] Adorno, T. W. (1942, 1946). 'Jazz', in: Encyclopedia of the Arts, ed. D. Runes and H. Shrikel (New York), pp. 511-513. Original German in Gesammelte Schriften, XVIII (1984), 70-73. (fide: Robinson, 1994).

[32] Darrell, R. D. (1932). 'Black Beauty', originally publ. in disques, pp. 152-161, reprinted in The Duke Ellington Reader, ed. Mark Tucker (Oxford: Oxford University Press, 1993) (fide: Leppert, 2002, p. 494).

[33] Howard, R. (2019). Pavarotti (Documentary movie). Polygram Entertainment and Decca Records, CBS Films, USA.

[34] Adorno, T. W. (1953b). 'Für und wider den Jazz', Merkur (September 1953), reprinted in Gesammelte Schriften, X/2 (1977), 805-809. (fide: Robinson, 1994).

[35] Franklin, A. (1972). Amazing Grace (double album). New York: Atlantic Records.

[36] Clark, N., \& Robinson, W. (2015). Aretha Franklin wins injunction to block screening at Telluride Film Festival. http://ew.com/article/2015

[37] LeRoi Jones, E. (1961, 1967). 'The Jazz Avant-Garde'. In: Black Music, pp. 69- 80. New York, Madison Avenue: Quill.

[38] Spellman, A. B. (1966, 1985 Ed.). 'Ornette Coleman'. In: Four Lives in the Bebop Business, pp. 77-150. New York: Limelight Editions.

[39] Case, B., \& Britt, S. (1978, 1979, 2nd Ed). 'Ornette Coleman'. In: The Illustrated Encyclopedia of Jazz, pp. 50-52. London: Salamander Books 1td.

[40] Case, B., \& Britt, S. (1978, 1979, 2nd Ed). 'John Coltrane'. In: The Illustrated Encyclopedia of Jazz, pp. 52-53. London: Salamander Books ltd.

[41] Coltrane, J. (1961). My Favorite Things (record). New York: Atlantic Records (Re-recorded at the Newport Jazz Festival, 1963, 1980 MCA Records Inc.)

[42] Rodgers, R., \& Hammerstein, O. (1959). 'My Favorite Things'. In: The Sound of Music (musical) New York: Original Broadway Production.

[43] Kofsky, F. (1980). Cover text of 1980 re-edition of 'My Favorite Things'. Williamson Music, MCA Records.

[44] Dylan, B. (Zimmerman, R. A.) (1966). Blonde on Blonde (double album). New York: Columbia Records.

[45] Allaerts, W. (2015). 'Van Passie voor modellen tot model voor passie' (lecture, not published) Enschede, 24 September 2015.

[46] Crick, F. (1988). What Mad Pursuit. A Personal View of Scientific Discovery. New York: Basic Books, p. 182.

[47] Watson, J. D. (2007). Avoid Boring People. (Lessons from a Life in Science). New York: Alfred A. Knopf Publ., p. 347.

[48] Pascal, B. (1652-1653). Discours sur les passions de l'amour. Bibliothèque municipal de Lisieux, B.P. 7216, 14107 Lisieux. http://www.bmlisieux.com

[49] Dabrowski, K., \& Piechowski, M. (1969). Les émotions supérieures et l'objectivité d'évaluation. Annales medico-psychologiques, 127(2), 589-613.

[50] Ackerman, C. M. (1997). Identifying gifted adolescents using personality characteristics: Dabrowski's overexcitabilities. Roeper Review, 19(4), 229-236. https://doi.org/10.1080/02783199709553835

[51] Dabrowski, K. (1970). Mental growth through positive disintegration. London: Gryf.

[52] Tillier, W. (2006). The philosophical foundation of Dabrowski's theory of positive disintegration. In: W. Tillier [Ed], Proceedings from the Seventh International Congress of the Institute of Positive Disintegration in Human Development, Calgary, AB, Canada.

[53] Lorre, C., \& Prady, B. (2007-2019). The Big Bang Theory (comedy series). Chuck Lorre Productions, Warner Bros Television.

[54] Berio, L. (1985). Two Interviews, p. 27. New York \& London: Marion Boyars (fide: Wikipedia.org).

[55] Adorno, T. W. (1949, 1976). Philosophie der neuen Musik). Gesammelte Schriften, XII (Hrsg. Rolf Tiedemann, 1976), Frankfurt am Main: Suhrkamp Taschenbuch Wissenschaft 239.

[56] AVROTROS. (2021). 'Vrijdagconcert'. Registration of concert at TivoliVredenburg, Utrecht, October 16th 2021, with Rotterdam Philharmonic Orchestra, Katia and Marielle Labèque, directed by John Adams and interview of Adams by Leonard Evers. Broadcasted by Avrotros (NPO 4) on October 29, 2021. 
[57] Jäger, L. (2005). Adorno. Eine politische Biographie, p. 32. München: Deutscher Taschenbuch Verlag (fide: Wikipedia.org)

[58] Adorno, T. W. (1962). 'Kierkegaard noch einmal. (Dem Andenken Paul Tillichs).' In: Kierkegaard: Konstruktion des Ästhetischen, p. 239 a.f. (Hrsgb. R. Tiedemann, 1962, Frankfurt am Main: Suhrkamp Verlag).

[59] Adorno, T. W. (1960). 'Mahler, Eine musikalische Physiognomik'. Frankfurt am Main. In: Gesammelte Schriften, XIII, pp. 149-319.

[60] Adorno, T. W. (1956, 2021). 'Schoenberg's Counterpoint'. (Engl transl. W. Hoban, 2021) In: The New Music: Kranichsteiner Lectures, Cambridge, UK, Medford, MA: Polity Press. (Hrsgb. von K. Reichert and M. Schwarz, 2014, Kranichsteiner Vorlesungen, Nachgelassene Schriften, Abteilung IV Band 17, Berlin: Suhrkamp Verlag).

[61] Kurth, E. (1917). Grundlagen des linearen Kontrapunkts: Einführung in Stil und Technik von Bach's melodischer Polyphonie (Bern: Drechsel) (cited in Adorno's 1955 Kranichsteiner lecture 3 on 'Der junge Schoenberg').

[62] Adorno, T. W. (1949, 2006). Philosophy of New Music (Eng. transl. R. Hullot-Kentor, 2006). Minneapolis: University of Minnesota Press.

[63] Adorno, T. W. (1966). Negative Dialectics. (Eng. transl. E.B. Ashton, 1983, New York: Continuum). Gesammelte Schriften, VI, pp. 7-412.

[64] Markus, W. (2018). Een feest waar hij niet naar toe zal gaan. Essays over Adorno, Mahler, Schönberg, Stravinsky, Messiaen, Boulez, e.a. Deel III. Permutatie in 8 stadia (in Dutch). Soest: Uitgeverij boek.scout.

[65] Žižek, S. (1994). Courtly Love, or, Woman as Thing. In: S. Žižek (1994, 2005). The Metastases of Enjoyment. On Women and Causality. New York, London: Radical Thinkers series, Verso, pp. 89-112.

[66] Allaerts, W. (2012). Slavoj Žižek, obscene interpreter between Hegel and Occupy movement. Enjoyment and view on women and causality. bi-logical, 4(1), 37-46.

[67] Adorno, T. W. (1969). "Zum Probleme der musikalischen Analyse” (Eng. transl. M. Paddison, 1982, On the problem of musical analysis, in: Music Analysis, 1(2), 169-187. German text in the journal of the Adorno Archiv, Frankfurter Adorno Blätter, 7 (2001), pp. 73-89).

[68] Winter, A. (2021). Zappa (Documentary). (Reconstructed from unpublished archive film material). https://www.ntr.nl

[69] Omroep MAX. (2021). Maatwerk. Radio broadcasting with Sander Zwiep, Dutch Radio NPO4, December 16th, 2021.

[70] Brandes, G. (1906). Reminiscences of my Childhood and Youth. New York: Duffield, pp. 276-277. 